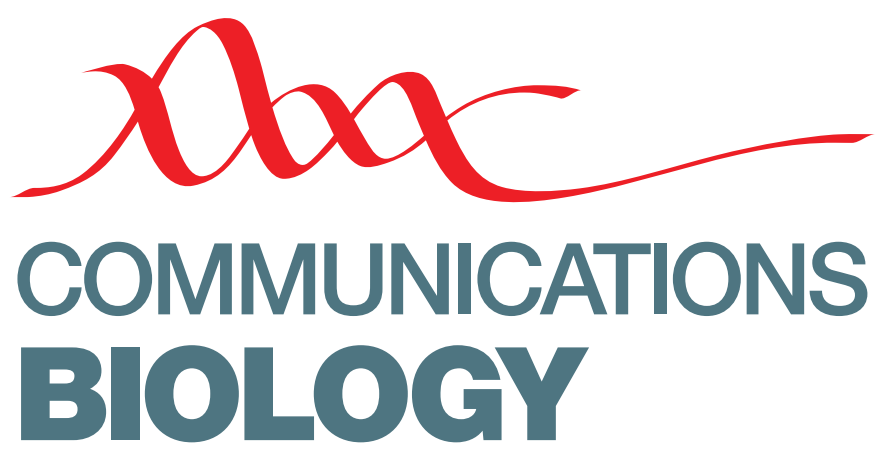

\title{
Publisher Correction: Dual roles of the sterol recognition region in Hedgehog protein modification
}

\author{
Rahul Purohit (1D, Daniel S. Peng (1D, Erika Vielmas \& \& Alison E. Ondrus
}

Correction to: Communications Biology https://doi.org/10.1038/s42003-020-0977-2, published online 21 May 2020.

In the original published version of the article, an error was introduced into Fig. 1a during the typesetting process. The error has been corrected in the PDF and HTML versions of the paper.

Published online: 02 June 2020

\begin{abstract}
(c) (i) Open Access This article is licensed under a Creative Commons Attribution 4.0 International License, which permits use, sharing, adaptation, distribution and reproduction in any medium or format, as long as you give appropriate credit to the original author(s) and the source, provide a link to the Creative Commons license, and indicate if changes were made. The images or other third party material in this article are included in the article's Creative Commons license, unless indicated otherwise in a credit line to the material. If material is not included in the article's Creative Commons license and your intended use is not permitted by statutory regulation or exceeds the permitted use, you will need to obtain permission directly from the copyright holder. To view a copy of this license, visit http://creativecommons.org/licenses/by/4.0/.
\end{abstract}

(c) The Author(s) 2020 